\title{
ANALISIS PENGAWASAN SELEKSI TERBUKA PENGISIAN JABATAN PIMPINAN TINGGI DI INSTANSI PEMERINTAH OLEH KOMISI APARATUR SIPIL NEGARA (KASN)
}

\author{
Della Damayanti, Mahendro Sumardjo, Alfatih S. Manggabarani \\ Universitas Pembangunan Nasional (UPN) Veteran Jakarta, Indonesia \\ Email: damayantidella912@gmail.com,msumardjo@yahoo.com, \\ alfatihsikki@gmail.com
}

\begin{abstract}
Abstrak
Penelitian ini merupakan penelitian kualitatif yang bertujuan untuk mengetahui bagaimana pelaksanaan pengisian jabatan pimpinan tinggi secara terbuka di Instansi Pemerintah dan pengawasan yang dilakukan oleh Komisi Aparatur Sipil Negara. Teknik pengumpulan data dalam penelitian ini adalah dengan melakukan wawancara mendalam dengan beberapa narasumber yang terkait dengan proses pelaksanaan seleksi terbuka pengisian jabatan pimpinan tinggi. Hasil Penelitian menunjukkan bahwa pelaksanaan seleksi terbuka pengisian jabatan pimpinan tinggi sudah merubah sistem manajemen ASN dari Close Career System menjadi Open Career System, sebagai sebuah sistem yang baru seleksi terbuka memiliki kelebihan dan kelemahan. Sedangkan pengawasan yang dilakukan KASN selama ini sudah cukup efektif baik secara preventif atau represif. Tujuan akhir dari manajemen ASN di Indonesia adalah manajemen talenta nasional, sehingga proses seleksi dapat diperoleh dari manajemen talenta nasional dan dapat melalui lintas instansi bahkan lintas sektor.
\end{abstract}

Kata Kunci: seleksi terbuka; pengawasan KASN; manajemen talenta nasional

\section{Abstract}

This research is qualitative research that aims to find out how the implementation of filling high leader positions in government instituion and the supervision carried out by the Indonesian Civil Service Commission. The data collection technique in this study was to conduct in-depth interviews with several resource persons related to the open selection process for filling high leadership positions. The results of the study indicate that the implementation of open selection for filling high leader positions has changed the ASN management system from the Close Career System to the Open Career System, as a new system, open selection has advantages and disadvantages. Meanwhile, the supervision carried out by KASN so far has been quite effective both preventively and repressively. The ultimate goal of ASN management in Indonesia is national talent management, so that the selection process is obtained from national talent management and can be cross-agency and even cross-sector.

Keywords: open selection; supervision KASN; national talent management

$\begin{array}{ll}\text { How to cite: } & \text { Damayanti. D., Mahendro Sumardjo \& Alfatih S. Manggabarani (2022) Analisis Pengawasan Seleksi Terbuka } \\ & \text { Pengisian Jabatan Pimpinan Tinggi Di Instansi Pemerintah Oleh Komisi Aparatur Sipil Negara (KASN). Syntax } \\ & \text { Literate: Jurnal Ilmiah Indonesia, 7(1). http://dx.doi.org/10.36418/Syntax-Literate.v7i1.6033 } \\ \text { E-ISSN: } & 2548-1398 \\ \text { Published by: } & \text { Ridwan Institute }\end{array}$


Received: 2021-12-20; Accepted: 2022-01-05; Published: 2022-01-15

\section{Pendahuluan}

Presiden Republik Indonesia telah menetapkan 5 prioritas kerja nasional tahun 2020-2024 salah satunya yaitu "Pembangunan Sumber Daya Manusia" bertujuan untuk meningkatkan sumber daya manusia yang berkualitas dan berdaya saing. Pada tahun 2011 Kementerian Pendayagunaan Aparatur Negara dan Reformasi Birokrasi, menyusun Grand Desain Reformasi Birokrasi dan Manajemen ASN. Dalam grand desain tersebut disusun 3 tahapan penting yaitu merubah career closed system menjadi career system dan yang terakhir yaitu menjadi open system. Sebagai salah satu bentuk untuk melakukan reformasi birokrasi khususnya berkaitan dengan ASN menuju human capital management, Pemerintah telah menerbitkan Undang-undang No. 5 Tahun 2014 tentang Aparatur Sipil Negara dengan mengusung sistem merit sebagai roh utama dalam manajemen ASN. Sistem merit didefinisikan sebagai kebijakan dan manajemen ASN berdasarkan kualifikasi, kompetensi, dan kinerja, yang diberlakukan secara adil dan wajar tanpa diskriminasi.

Salah satu wujud implementasi sistem merit yaitu diterapkan proses seleksi terbuka dalam pengisian jabatan pimpinan tinggi di seluruh Instansi Pemerintah dengan tujuan untuk mendapatkan ASN yang tepat sesuai dengan kebutuhan organisasi. Namun sampai saat ini, seleksi terbuka belum dapat menciptakan sistem rekrutmen dengan persaingan yang adil dan terbuka untuk menciptakan Aparatur Sipil Negara yang profesional, Integritas, berkinerja tinggi, dan penempatannya sesuai dengan prinsip merit sistem karena masih banyaknya kepentingan dari beberapa pihak. Pada praktiknya pelaksanaan tersebut diwarnai dengan praktik kolusi, korupsi dan nepotime (KKN) yang masih belum bisa dihilangkan karena berkaitan dengan politik. Selain itu, proses tersebut juga didukung oleh lemahnya sistem pengawasan yang diterapkan baik oleh pihak internal maupun eksternal. Pada faktanya saat ini setelah berjalan kurang lebih 5 tahun pelaksanaan pengisian JPT di lingkungan Instansi Pemerintah secara terbuka masih ditemukan kasus pelanggaran dalam proses tersebut, sebagaimana digambarkan pada data dibawah ini. 
Della Damayanti, Mahendro Sumardjo, Alfatih S. Manggabarani

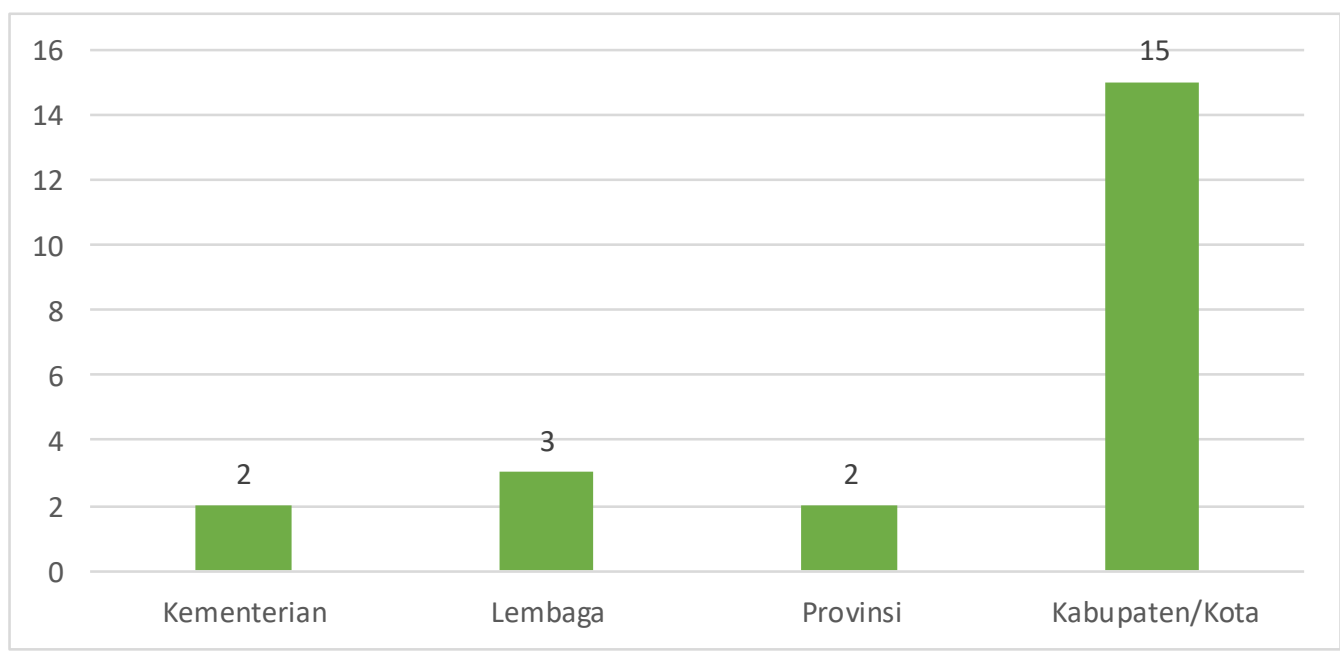

\section{Gambar 1}

Sumber: Data diolah oleh peneliti dari Komisi Aparatur Sipil Negara Pokja JPT Wilayah I, 2020

Dari data tersebut terlihat masih terdapat kasus pelanggaran dalam pelaksanaan seleksi terbuka untuk pengisian Jabatan Pimpinan Tinggi, terutama di wilayah Kabupaten/Kota dikarenakan masih tingginya unsur politis. Pada tahun 2020, tercatat 2.430 rekomendasi yang telah dikeluarkan oleh KASN guna menunjang pelaksanaan pengisian Jabatan Pimpinan Tinggi (JPT) berjalan secara terbuka dan kompetitif di seluruh Instansi Pemerintah. Dari beberapa pelaksanaan proses seleksi terbuka tersebut, pada tahun 2020 KASN sudah melakukan 18 kali mediasi atas pelaksanaan rekomendasi yang dikeluarkan oleh KASN untuk memastikan pelaksanaan pengisian JPT berjalan adil dan sesuai dengan regulasi. Kondisi ini di dukung oleh Komisi Pemberantasan Korupsi (KPK) yang menyebut bahwa kasus dugaan suap jual-beli jabatan lebih banyak terjadi di berbagai daerah karena Kepala Daerah yang notabene berasal dari politik merasa tak diawasi.

\section{Tabel 1}

State of the Art

\begin{tabular}{|c|c|c|c|c|}
\hline No. & Judul & $\begin{array}{c}\text { Nama Peneliti } \\
\text { dan Tahun }\end{array}$ & Metode & Hasil Penelitian \\
\hline 1. & $\begin{array}{l}\text { "Recruitment and } \\
\text { Selection Strategies of } \\
\text { Public Sector } \\
\text { Untertakings" }\end{array}$ & (Sajeena, 2017) & Kuantitatif & $\begin{array}{l}\text { Strategi rekrutmen dan seleksi di } \\
\text { sektor publik yaitu berdasarkan } \\
\text { atas kualifikasi dan pengalaman } \\
\text { karyawan serta dilakukan dengan } \\
\text { metode secara langsung yaitu } \\
\text { melakukan talent scouting dari } \\
\text { berbagai universitas terbaik, head } \\
\text { hunter, serta membuat waiting list } \\
\text { (suksesor) dari internal perusahan. }\end{array}$ \\
\hline 2. & $\begin{array}{l}\text { "Effctiveness of } \\
\text { Recruitment and } \\
\text { Selection Practices in } \\
\text { Public Sector Higher }\end{array}$ & $\begin{array}{l}\text { (Isaac } \\
\text { Christopher } \\
\text { Otoo, Juliet } \\
\text { Assuming, } \\
\end{array}$ & Kuantitatif & $\begin{array}{l}\text { Praktik perekrutan di lembaga } \\
\text { pendidikan tinggi sektor publik } \\
\text { Ghana tidak efektif karena } \\
\text { mengandalkan rekomendasi dalam }\end{array}$ \\
\hline
\end{tabular}




\begin{tabular}{|c|c|c|c|c|}
\hline & $\begin{array}{l}\text { Education Institutions : } \\
\text { Evidence from Ghana" }\end{array}$ & 2018) & & $\begin{array}{l}\text { memilih seseorang sehingga } \\
\text { mengarah pada favoritisme, } \\
\text { keberpihakan sehingga muncul } \\
\text { adanya bias dalam perekrutan. }\end{array}$ \\
\hline 3. & $\begin{array}{l}\text { "Comparative Analysis } \\
\text { of Recruitment Systems } \\
\text { in the Public Sector in } \\
\text { Greece and Europe: } \\
\text { Trends and Outlook for } \\
\text { Staff Selection Systems } \\
\text { in the Greek Public } \\
\text { Sector" }\end{array}$ & $\begin{array}{l}\text { (Ifaistion, } \\
\text { Ioannis, \& } \\
\text { George, 2017) }\end{array}$ & Kualitatif & $\begin{array}{l}\text { Perbandingan menunjukkan bahwa } \\
\text { proses seleksi di Eropa lebih baik } \\
\text { dibandingkan di Yunani. Meskipun } \\
\text { Yunani sedang berupaya untuk } \\
\text { reformasi dan merampingkan } \\
\text { sistem perekrutan namun terdapat } \\
\text { hambatan diantaranya yaitu tidak } \\
\text { ada kebijakan yang jelas, deskripsi } \\
\text { pekerjaan yang buruk, terdapat } \\
\text { "celah" dalam sistem rekrutmen, } \\
\text { minimnya profesi dan strategi atau } \\
\text { prosedur yang berhubungan dengan } \\
\text { manajemen personalia secara } \\
\text { objektif. }\end{array}$ \\
\hline 4. & $\begin{array}{l}\text { "Examining the Public } \\
\text { Sector Recruitment and } \\
\text { Selection, in relation to } \\
\text { job analysis in } \\
\text { Pakistan" }\end{array}$ & (Ashraf, 2017) & Kuantitatif & $\begin{array}{l}\text { Proses rekrutmen di sektor publik } \\
\text { pakistan "buruk" karena } \\
\text { melakukan analisis pekerjaan } \\
\text { dengan buruk. Tidak membuat } \\
\text { uraian tugas yang benar dan } \\
\text { karyawan tidak diberikan tugas } \\
\text { yang sesuai dengan job description } \\
\text { yang pada akhirnya mempengaruhi } \\
\text { kinerja sektor publik di Pakistan. }\end{array}$ \\
\hline 5 . & $\begin{array}{l}\text { "Employee Inerest in } \\
\text { Following Promotion } \\
\text { Selection Through Open } \\
\text { Bidding" }\end{array}$ & $\begin{array}{l}\text { (Barusman, } \\
\text { 2018) }\end{array}$ & Kualitatif & $\begin{array}{l}\text { Terdapat lima faktor yang } \\
\text { mempengaruhi minat karyawan } \\
\text { dalam seleksi terbuka yaitu: 1) } \\
\text { Dedikasi dan Aktualisasi; 2) } \\
\text { Pengalaman dan pengetahun; 3) } \\
\text { Pendidikan dan Jabatan; 4) Faktor } \\
\text { Mental dan Tanggung Jawab; dan } \\
\text { 5) Pendapatan. Di antara faktor- } \\
\text { faktor ini, Faktor Pengalaman dan } \\
\text { pengetahuan ditemukan sebagai } \\
\text { faktor pengaruh yang paling } \\
\text { dominan. }\end{array}$ \\
\hline 6. & $\begin{array}{l}\text { "Transactional Politics } \\
\text { in Filling High } \\
\text { Leadership Positions in } \\
\text { Indonesian Bureaucratic } \\
\text { Organizations" }\end{array}$ & $\begin{array}{l}\text { (Suwitri, } \\
\text { Supriyono, } \\
\text { Sulastri, \& } \\
\text { Kuswandaru, } \\
\text { 2019) }\end{array}$ & Kualitatif & $\begin{array}{l}\text { Penerapan sistem merit dalam } \\
\text { mengisi JPT di berbagai } \\
\text { kementerian / lembaga ditandai } \\
\text { dengan praktik jual dan beli } \\
\text { jabatan, bahkan semakin masif } \\
\text { intensitasnya. ASN berada dalam } \\
\text { posisi dilematis dan terombang- } \\
\text { ambing oleh kepentingan politik. }\end{array}$ \\
\hline 7. & $\begin{array}{l}\text { "Challenges with } \\
\text { Implementation of the } \\
\text { Merit System in the } \\
\text { Open Recruitment of } \\
\text { Government High }\end{array}$ & $\begin{array}{l}\text { (Dwiputrianti, } \\
\text { 2018) }\end{array}$ & Kualitatif & $\begin{array}{l}\text { Terdapat beberapa masalah untuk } \\
\text { menerapkan manajemen ASN } \\
\text { berbasis merit, terutama dalam } \\
\text { pengisian Jabatan Pimpinan Tinggi } \\
\text { secara terbuka. }\end{array}$ \\
\hline
\end{tabular}




\begin{tabular}{|c|c|c|c|c|}
\hline & $\begin{array}{l}\text { Position: The Case in } \\
\text { Indonesia" }\end{array}$ & & & \\
\hline 8. & $\begin{array}{l}\text { "Analisis Pelaksanaan } \\
\text { Seleksi Terbuka bagi } \\
\text { Pengisian Jabatan } \\
\text { Pimpinan Tinggi di } \\
\text { Indonesia" }\end{array}$ & (Noors, 2019) & Kualitatif & $\begin{array}{l}\text { Pelaksanaan sistem merit tidak } \\
\text { berjalan optimal karena } \\
\text { pelaksanaan seleksi terbuka di } \\
\text { setiap pengisian jabatan untuk JPT } \\
\text { masih kental dengan nuansa spoil } \\
\text { system. }\end{array}$ \\
\hline
\end{tabular}

Penelitian terkait pengisian jabatan pimpinan tinggi melalui seleksi terbuka bukanlah sesuatu hal yang baru untuk dijadikan tema dalam sebuah penelitian, sebagaimana dijelaskan pada state of the art penelitian terdahulu diatas. Namun, selain menekankan pada pelaksanaan pengisian jabatan pimpinan tinggi di Instansi Pemerintah, pada penelitian ini dilakukan peninjauan lebih lanjut terkait peningkatan fungsi dan peran aktif KASN dalam sistem pengawasan pengisian JPT yang mampu menciptakan transparansi dan obyektifitas, dengan mempertimbangkan resiko pelanggaran yang belum dianalisis pada penelitian-penelitian sebelumnya. Komisi Aparatur Sipil Negara sebagai lembaga nonstruktural yang mandiri dan bebas dari intervensi politik yang berfungsi mengawasi penerapan nilai dasar, kode etik dan kode perilaku pegawai ASN serta penerapan sistem merit dalam kebijakan dan manajemen ASN, diberikan kewenangan untuk mengawasi setiap proses manajemen ASN agar sesuai dengan sistem merit, salah satunya yaitu mengawasi tahapan seleksi pengisian JPT baik secara preventif dan represif. Oleh karena itu, peneliti merumuskan pokok permasalahan yang akan diteliti dalam penelitian ini yaitu: Bagaimana praktik seleksi terbuka pengisian Jabatan Pimpinan Tinggi di Instansi Pemerintah dan pengawasan yang dilakukan oleh Komisi Aparatur Sipil Negara. Serta tujuan dari penelitian ini adalah untuk menganalisis pelaksanaan dan pengawasan seleksi terbuka Pengisian Jabatan Pimpinan Tinggi di Instansi Pemerintah oleh KASN.

\section{Metode Penelitian}

Metode yang digunakan dalam penelitian ini yaitu metode kualitatif. (Sugiyono, 2017) menjelaskan pengertian metode kualitatif merupakan penelitian yang digunakan untuk meneliti pada kondisi objek yang alamiah, dimana peneliti adalah sebagai instrumen kunci, teknik pengumpulan data dilakukan secara triangulasi (gabungan), analisis data bersifat induktif dan hasil penelitian kualitatif lebih menekankan makna dari pada generalisasi. Penelitian ini merupakan penelitian kualitatif karena bertujuan untuk menggambarkan fenomena atau masalah yang terjadi dalam proses seleksi terbuka pengisian jabatan pimpinan tinggi di Instansi Pemerintah yang dianalisis secara deskriptif. Dalam penelitian kualitatif ini, peneliti menggunakan paradigma interpretivisme dan pendekatan fenomenologi sebagai cara peneliti memandang fokus penelitian dan menentukan cara pengumpulan data serta analisis data.

Pemilihan lokasi pada penelitian ini dilakukan di Komisi Aparatur Sipil Negara (KASN) sebagai lembaga yang memiliki kewenangan untuk melakukan pengawasan terhadap pelaksanaan seleksi terbuka pengisian Jabatan Pimpinan Tinggi di Instansi 
Pemerintah. Sedangkan objek dalam penelitian ini yaitu proses pengawasan pelaksanaan seleksi terbuka pengisian Jabatan Pimpinan Tinggi (JPT) di Instansi Pemerintah yang dilakukan oleh KASN selama ini. Data primer yang dihimpun langsung oleh peneliti dari hasil observasi terhadap situasi sosial dan atau diperoleh dari tangan pertama atau subjek (informan) melalui proses wawancara. Peneliti melakukan wawancara mendalam dengan beberapa informan yang terkait, diantaranya yaitu : Komisioner KASN Bidang pengawasan jabatan pimpinan tinggi wilayah I, Panitia Seleksi Terbuka, dan Badan Kepegawaian Daerah. Sedangkan data sekunder diperoleh secara tidak langsung oleh peneliti dari buku, artikel, jurnal, peraturan pemerintah dan dokumen-dokumen lainnya yang berhubungan dengan pelaksanaan seleksi terbuka pengisian Jabatan Pimpinan Tinggi di Instansi Pemeritah.

Validitas data pada penelitian kualitatif merupakan derajat ketepatan antara data yang terjadi pada objek penelitian dengan data yang dapat dilaporkan peneliti. Persyaratan data dianggap memiliki kredibilitas atau tingkat kepercayaan yang tinggi yaitu terdapat kesesuaian antara fakta di lapangan yang dilihat dari pandangan atau paradigma informan, narasumber ataupun partisipan dalam penelitian. Validitas data dilakukan melalui proses triangulasi, menurut (Sugiyono, 2017) Triangulasi diartikan sebagai pengecekan data dari berbagai sumber dengan berbagai cara, dan berbagai waktu untuk meningkatkan keabsahan data. Triangulasi dalam penelitian ini menggunakan teknik triangulasi sumber dan teknik. Kegiatan analisa data dalam penelitian ini menggunakan model analisa interaktif Miles dan Huberman dalam (Sugiyono, 2017) melalui empat tahapan sebagai berikut:

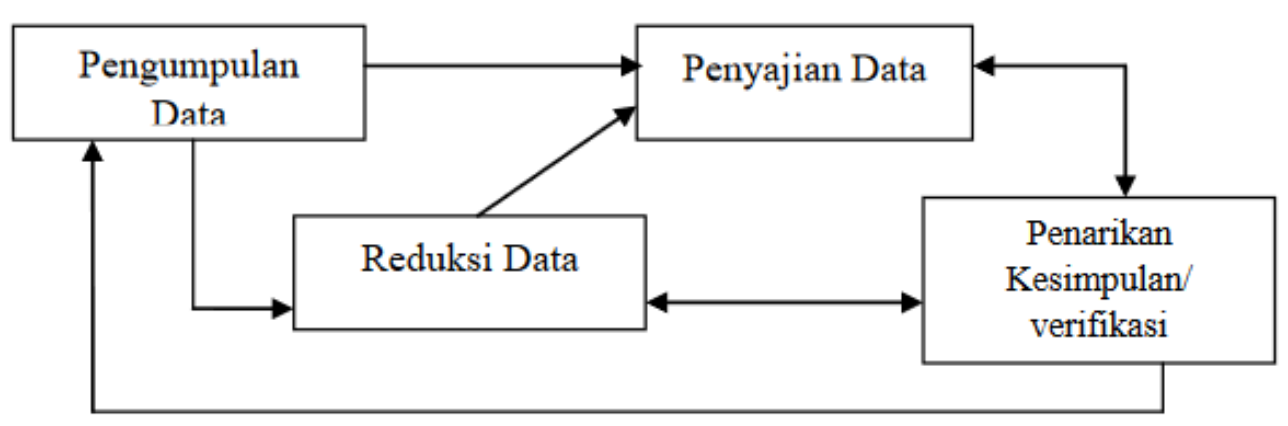

Gambar 2

Sumber: (Sugiyono, 2017)

\section{Hasil dan Pembahasan}

Sistem merit adalah kebijakan dan manajemen Sumber Daya Manusia yang mengutamakan kualifikasi, kompetensi, dan kinerja dalam seleksi, mutasi, promosi, penggajian, dan pemberhentian pegawai ASN. Sistem merit menjamin perlakukan yang objektif, adil dan wajar tidak membedakan latar belakang politik, ras, warna kulit, agama, asal usul, jenis kelamin, status pernikahan, umur dan kondisi kecacatan. Untuk menerapkan sistem merit dalam kebijakan dan manajemen ASN, Pemerintah telah 
menerbitkan Undang-Undang No 5 Tahun 2014 tentang Aparatur Sipil Negara (ASN) untuk menciptakan ASN yang berintegritas, Netral, dan Profesional. Pengisian Jabatan Pimpinan Tinggi (JPT) secara terbuka merupakan salah satu penerapan sistem merit dalam manajemen ASN. Sebelum adanya Undang-Undang ASN yang mengamanatkan manajemen ASN berbasis merit sistem, pengisian jabatan pimpinan tinggi dilakukan berdasarkan daftar urut kepangkatan (DUK), pengisian jabatan tidak berdasarkan kompetensi dan kinerja, hanya berdasarkan pada tingkat kepangkatan dan senioritas, pengisian jabatan pun menjadi tertutup karena hanya diperoleh dari Internal Instansi Pemerintah itu sendiri. Dengan lahirnya Undang-Undang ASN dan Komisi Aparatur Sipil Negara, maka mulai diterapkanlah pengisian jabatan pimpinan tinggi untuk menggantikan close career system menjadi open career system. Hal ini didukung dalam penelitian yang dilakukan oleh (Ali, Prasojo, \& Lina, 2017) dengan judul "The Transformation of Merit System Civil Servant Promotion System" yang membuktikan bahwa untuk saat ini model seleksi terbuka memang menjadi prosedur terbaik untuk membentuk ASN yang profesional dan menggambarkan implementasi sistem merit dalam sistem promosi dan seleksi manajemen kepegawaian publik.

Secara teknis pengisian jabatan secara terbuka diatur dalam Peraturan Menteri Pendayagunaan Aparatur Negara dan Reformasi Birokasi Nomor 13 Tahun 2014 tentang Tata Cara Pengisian Jabatan Pimpinan Tinggi (JPT) secara terbuka di Lingkungan Instansi Pemerintah. Sebagai sebuah sistem yang baru untuk menggantikan sistem yang sudah ada sebelumnya, pelaksanaan pengisian jabatan pimpinan tinggi secara terbuka tidak terlepas dengan adanya resistensi yang terjadi sebagai bentuk dampak dari adanya manajemen perubahan. Berikut evaluasi dalam pelaksanaan seleksi terbuka baik dari segi kelemahan ataupun kelebihannya.

\section{Kelemahan Pelaksanaan Seleksi Terbuka}

\section{a. Biaya dan Waktu Pelaksanaan}

Dengan adanya perubahan open career system, Instansi Pemerintah diharuskan untuk mengganggarkan biaya lebih untuk manajemen ASN, khususnya untuk pelaksanaan seleksi terbuka sebagai sebuah sistem yang baru. Pelaksanaan seleksi terbuka menjadi mahal dikarenakan pembiayaan untuk penilaian kompetensi melalui assessment center per individu pelamar yang cukup besar. Assessment center merupakan metode untuk menggali kompetensi perilaku seseorang sehingga dapat ditemukan area kekuatan maupun kompetensi yang perlu dikembangkan oleh individu melalui sejumlah simulasi.

Selain dari segi pembiayaan, proses pelaksanaan seleksi terbuka yang terlalu lama menjadi salah satu kendala yang terjadi. Proses seleksi dari mulai Pengumuman, seleksi administrasi, seleksi kompetensi dan sampai pengumuman akhir memakan waktu 3 bulan lebih. Sampai pejabat terpilih akan dilakukan proses tes kesehatan, dan administrasi hingga pejabat terpilih tersebut dilantik. Sehingga apabila dilihat dari awal pengumuman sampai pejabat tersebut duduk di jabatan yang diisi akan memakan waktu kurang lebih 4 bulan. 
Pembiayaan yang mahal dan waktu pelaksanaan yang cukup lama seringkali mengakibatkan terjadinya gap kekosongan jabatan. Dengan adanya kekosongan jabatan maka jabatan tersebut ditempati sementara oleh Pelaksana Tugas (Plt). Kondisi tersebut tidak dapat memaksimalkan jalannya birokrasi, karena pegawai harus memegang 2 jabatan sekaligus. Selain itu, tidak semua Plt yang diberikan tugas memahami secara penuh terhadap jabatan sementara yang diembannya. Berdasarkan Undang-Undang Nomor 30 Tahun 2014 tentang Administrasi Pemerintahan seorang Plt tidak berwenang mengambil keputusan dan/atau tindakan yang bersifat strategis dan berdampak besar seperti kebijakan terkait anggaran, kepegawaian, hukum dan sebagainya. Meskipun dalam Peraturan Menteri Aparatur Negara Nomor 13 Tahun 2014 tentang Tata Cara Pengisian Pimpinan Tinggi, dijelaskan bahwa masa jabatan Plt maksimal 3 bulan dan dapat diperpanjang paling lama tiga bulan lagi. Namun, Komisioner KASN memberikan saran untuk dapat melakukan seleksi terbuka sebelum pejabat tersebut pensiun, agar tidak terjadi kekosongan jabatan.

\section{b. Pejabat yang terpilih}

Selain dalam proses pelaksanaannya, hasil dari seleksi terbuka pengisian JPT tidak dapat menjamin seutuhnya bahwa pejabat yang dipilih tersebut memang berkompeten. Bahkan sering terjadi, saat proses seleksi terbuka dilaksanakan, tidak banyak ASN yang bersedia untuk melamar, sehingga peserta yang mengikuti seleksi terbuka memang terkadang bukan orang-orang yang sesuai dengan jabatan yang akan diisi, namun adanya dorongan bahkan paksaan kepada pegawai tersebut untuk mengikuti seleksi. Kondisi ini memang terjadi akibat tidak adanya data base khusus yang berisi tentang talenta talenta terbaik yang ada, sehingga seleksi dibuka sebagai bentuk free competition, siapa saja dapat melamar. Jadi pemilihan hasil seleksi terbuka dapat diartikan memilih pelamar yang terbaik dari yang terburuk melamar. Muncul adanya bias antara hasil seleksi terbuka dengan kompetensi jabatan yang akan diisi.

Selain dari sisi jumlah yang melamar, tools untuk menguji kompetensi calon peserta melalui assessment dinilai sangat general. Hal ini dikarenakan belum adanya kompetensi teknis yang disusun berdasarkan jenis jabatan. Sedangkan setiap jabatan memiliki kompetensi berbeda-beda sesuai dengan bidangnya masing-masing. Standar Kompetensi Jabatan diatur dalam Peraturan Menteri Pendayagunaan Aparatur Negara dan Reformasi Birokrasi Nomor 38 Tahun 2017 tentang Standar Kompetensi Jabatan Aparatur Sipil Negara, namun dalam peraturan ini hanya mengatur standar kompetensi manajerial dan kompetensi sosial kultural, sedangkan kompetensi teknis disusun oleh Menteri/Pimpinan Lembaga di bidang urusan pemerintah yang relevan, namun apabila kompetensi teknis belum ditetapkan oleh Menteri/Pimpinan Lembaga di bidang urusan pemerintah tertentu, maka setiap instansi dapat menyurun kompetensi teknis sendiri. Namun, kondisi ini memang sangat dipahami dengan keterbatasan pengelola kepegawaian di masing-masing Instansi Pemerintah 
khususnya di Pemerintah Daerah, yang merasa kesulitan untuk menyusun standar kompetensi bidang tugas masing-masing jabatan. Standar kompetensi teknis seharusnya disusun oleh Kementerian/Lembaga yang membidangi masing-masing sektor. Dengan adanya standar kompetensi teknis dan bidang yang lebih spesifik maka hasil pejabat yang dipilih dari proses seleksi memang betul betul sesuai dengan jabatan yang diisi baik secara kompetensi manajerial maupun teknis.

Data dari hasil penilaian penerapan sistem merit oleh Komisi Aparatur Sipil Negara tahun 2021, dari jumlah 109 Instansi Pemerintah yang sudah melakukan penilaian penerapan sistem merit, terdapat 35 Instansi Pemerintah yang belum menyusun standar kompetensi jabatan, bahkan untuk Jabatan Pimpinan Tinggi itu sendiri. Dengan belumnya disusun standar kompetensi jabatan ini, bagaimana cara mengetahui kebutuhan kompetensi dan menilai kompetensi calon yang akan menduduki jabatan tersebut. Kondisi ini menjadi tugas bersama, terutama dari masing-masing Instansi baik pusat atau daerah, BKN, Kemenpan, dan Kementerian/Lembaga yang membidangi masing-masing sektor.

Beberapa kelemahan yang telah dijelaskan sebelumnya, juga telah dibuktikan dalam penelitian yang dilakukan oleh (Ali et al., 2017) dengan judul "Recruitment Analysis Through Open Bidding Announcement in the Selection of Prospective Echelon II" dalam hasil penelitian tersebut dinyatakan bahwa perekrutan terbuka belum benar-benar berjalan sesuai yang diharapkan. Hal ini diakibatkan karena kendala waktu dan proses yang cukup lama, peraturan yang masih belum jelas, serta analisis kebutuhan jabatan yang kurang jelas dan akurat.

\section{Kelebihan Pelaksanaan Seleksi Terbuka}

\section{a. Adanya Persaingan}

Dengan adanya proses seleksi secara terbuka, para pelamar diwajibkan untuk melewati beberapa proses tahapan baik administrasi dan penilaian kompetensi (assessment, penulisan makalah, dan wawancara). Kondisi tersebut bertujuan untuk dapat menggali kompetensi serta muncul rasa kompetitif diantara para pelamar. Hal ini yang mengakibatkan para pelamar bekerja keras untuk dapat memberikan hasil yang terbaik, dan terjadinya persaingan yang sangat ketat untuk dapat mengisi jabatan yang lowong. Melalui seleksi terbuka dalam pengisian jabatan membuat setiap ASN memiliki peluang dan kesempatan yang sama untuk duduk dalam suatu jabatan tertentu selama memiliki kompetensi seperti yang dibutuhkan. ASN yang tidak dapat mengembangkan kompetensi yang dimiliki akan secara langsung tereliminasi oleh ASN lain yang memiliki kompetensi lebih.

Dengan demikian, akan lebih mudah menemukan ASN yang handal dan profesional karena meningkatnya persaingan dalam rangka menunjukkan kualitas yang dimiliki. Sebagaimana disampaikan oleh (Yusuf, 2018) manfaat promosi jabatan yaitu meningkatkan semangat dan gairah kerja karyawan, 
menciptakan persaingan yang sehat, membina jenjang karir karyawan, mengembangkan kemampuan karyawan, mengisi formasi jabatan tertentu dengan memanfaatkan sumber daya manusia dari dalam perusahaan dan sebagai jaminan bagi karyawan bahwa setiap karyawan akan diberi kesempatan untuk maju.

\section{b. Munculnya regenerasi}

Berdasarkan hasil kajian yang dilakukan oleh (Irfan, 2017) terdapat beberapa kelebihan dari seleksi terbuka jabatan ASN salah satunya yaitu mempercepat regenerasi. Sistem karier terbuka memberikan peluang bagi PNS yang telah memenuhi persyaratan mengikuti seleksi pengisian JPT di luar instansinya. Dengan demikian, terbuka luas bagi setiap PNS yang memiliki kompetensi tertentu untuk mengembangkan karirnya di lingkup instansi pemerintah Pusat maupun Daerah. Pelaksanaan seleksi terbuka yang tidak berdasarkan senioritas, namun berdasarkan kompetensi ini, membuka kesempatan bagi siapapun untuk dapat melamar, namun dengan catatan secara kualifikasi dan kompetensi sudah terpenuhi. Oleh karena itu muncullah generasi generasi baru yang memang memiliki kemampuan bagus dan dapat bersaing dengan yang lainnya. Dengan munculnya generasi baru yang berkompeten dan berintegritas, dapat menciptakan birokrasi Indonesia semakin maju dengan ide ide yang lebih fresh akan membawa pemerintahan indonesia dapat bersaing dengan negara lainnya.

\section{Panitia Seleksi}

Salah satu pihak yang memiliki peran penting dalam pelaksanaan seleksi terbuka pengisian Jabatan Pimpinan Tinggi adalah Panitia Seleksi. Panitia seleksi merupakan tim yang terdiri dari beberapa orang kompeten yang dibentuk oleh Pejabat Pembina Kepegawaian (PPK) masing-masing Instansi Pemerintah dan diberikan tugas untuk melakukan seleksi secara adil, terbuka, dan objektif. Panitia seleksi harus berjumlah ganjil yaitu paling sedikit 5 orang dan paling banyak 9 orang. Sebanyak banyaknya terdiri dari $45 \%$ unsur internal yaitu pejabat terkait dari lingkungan instansi pemerintah yang bersangkutan dan sekurang kurangnya 55\% dari unsur eksternal yaitu pejabat dari instansi lain atau akademisi/pakar/profesional. Kedua unsur eksternal tersebut harus memiliki kualifikasi bidang dan tugas jabatan yang lowong serta menguasai manajemen SDM. Panitia seleksi yang diharapkan memegang kendali utama dalam melaksanakan seleksi terbuka pengisian Jabatan Pimpinan Tinggi, namun kerap kali ditemukan dilapangan bahwa panitia seleksi melakukan kecurangan dan ketidakobjektifan dalam proses menilai para pelamar. Ketidakobjektifan pansel ini dilakukan dengan berbagai cara, yaitu sebagai berikut:

a. Merubah persyaratan administrasi seperti yang terjadi di Pemkab Timor Tengah Selatan (TTS), saat pelaksanaan Panitia Seleksi Pejabat Eseleon II terjadi kecurangan Pansel dengan merubah persyaratan pengalaman jabatan administrator dari 5 tahun menjadi 3 tahun. Padahal sesuai Peraturan Pemerintah (PP) No. 11 Tahun 2017 tentang Manajemen ASN, pasal 107 huruf C, poin 3 
menganatkan pengalaman jabatan administrator dalam jabatan pimpinan tinggi pratama secara komulatif paling kurang 5 tahun. Sehingga banyak peserta yang tidak memenuhi syarat administrasi namun tetap dinyatakan lulus.

b. Merubah bobot penilaian, khususnya di bobot penilaian wawancara. Pada kenyataannya usaha panitia seleksi untuk memenangkan seseorang, dengan cara memberikan bobot penilaian assessment lebih kecil dibandingkan dengan wawancara. Pada dasarnya tahapan assessment merupakan tahapan penilaian yang sangat objektif karena memang menilai langsung berdasarkan sikap dan kompetensi calon secara sistematis, sedangkan tahapan wawancara kerap memiliki objektifitas rendah dan cenderung subjektifitas. Sehingga hasil seleksi cenderung tidak objektif untuk memenangkan salah satu calon.

Selain itu, kondisi ini juga didukung dari hasil penelitian dalam jurnal dengan judul The Prevention of Corruption Risk Through The Improvement of Open Selection System For Top Leadership Position in Local Government yang disusun oleh (Achmad, 2017) bahwa prosedur dan mekanisme pelaksanaan promosi terbuka untuk posisi pimpinan puncak di pemerintah daerah masih menyediakan ruang untuk korupsi, seperti dalam pembentukan panitia seleksi, mekanisme dalam menentukan hasil seleksi, dan mekanisme evaluasi. Pada dasarnya KASN sudah memiliki Kode Etik dan Kode Perilaku Panitia Seleksi Jabatan Pimpinan Tinggi yang dituangkan dalam Peraturan Komisi Aparatur Sipil Negara Nomor 4 Tahun 2017 tentang Kode Etik dan Kode Perilaku Panitia Seleksi Jabatan Pimpinan Tinggi di Lingkungan Instansi Pemerintah. Namun terkadang, kode etik dan kode perilaku panitia seleksi tersebut, tidak diimplementasikan dengan baik oleh beberapa panitia seleksi, sehingga masih banyaknya pelanggaran yang dilakukan oleh panitia seleksi.

Ketidak objektifan ataupun segala bentuk pelanggaran yang dilakukan panitia seleksi akan mendapatkan sanksi oleh KASN, sanksi yang diberikan baik berupa sanksi moral teguran baik lisan maupun tertulis, dan sanksi administrasi berupa pemberhentian atas rekomendasi KASN dari anggota panitia seleksi ketika seleksi sedang berlangsung serta pelarangan oleh KASN untuk menjadi anggota panitia seleksi untuk jangka waktu tertentu. Namun, KASN belum mempunyai sebuah sistem yang mengelola data pantia seleksi, diharapkan data panitia seleksi terintegrasi dalam satu sistem dan apabila pansel yang sudah terkena kasus di blacklist oleh KASN dapat terrecord, sehingga secara otomatis tidak dapat menjadi panitia seleksi kembali untuk pengisian jabatan pimpinan tinggi di seluruh instansi pemerintah sesuai dengan peraturan yang berlaku.

Selain upaya represif, KASN juga melakukan upaya preventif untuk meminimalisir pelanggaran yang dilakukan oleh Panitia Seleksi salah satunya melakukan workshop dan webinar yang dihadiri oleh panitia seleksi dari berbagai Instansi Pemerintah baik Pusat dan Daerah. Peserta dibekali dengan pendalaman materi baik secara teori, konsep, metode dan praktis yang dapat diimplementasikan dalam pelaksanaan seleksi terbuka di Indonesia, pembelajaran dari studi kasus, serta 
solusi pemecahan berbagai masalah yang kerap ditemukan dalam pelaksanaan seleksi terbuka.

Sangat disadari upaya yang dilakukan KASN baik secara preventif dan represif untuk mengawasi panitia seleksi yang melakukan kecurangan atau ketidakobjektifan sudah dilakukan dengan cukup baik. Namun kondisi ini harus dibarengi dengan kesadaran dan pemahaman mendalam terkait sistem merit, mekanisme dan aturan seleksi terbuka dari Panitia Seleksi itu sendiri serta PPK dan pengelola kepegawaian di masing-masing untuk lebih objektif dalam melaksanakan proses seleksi terbuka. Apabila secara sistem, peraturan dan tahapan seleksi sudah baik, namun panitia seleksi dan PPK yang memiliki peran besar tidak memahami makna dari sistem merit, dengan melakukan kecurangan dan tidak objektif dalam pelaksanaan seleksi terbuka maka tidak dapat menciptakan open career system yang diharapkan berbasis merit sistem.

\section{Pengawasan KASN}

Komisi Aparatur Sipil Negara sebagai lembaga non struktural yang dibentuk atas lahirnya Undang-Undang 5 Tahun 2014 tentang Aparatur Sipil Negara, mempunyai tugas sebagai lembaga pengawas pelaksanaan manajemen ASN berbasis merit sistem, salah satu prakteknya yaitu pelaksanaan seleksi terbuka. Secara teknis dalam melakukan pengawasan, KASN sudah mempunyai Pedoman Pengawasan atas Pengisian Jabatan Pimpinan Tinggi pada Instansi Pemerintah yang dituangkan di dalam Peraturan Komisi Aparatur Sipil Negara Nomor 2 Tahun 2017. Pedoman ini dimaksudkan untuk menjadi panduan bagi pegawai KASN dalam melaksanakan tugasnya mengawasi pelaksanaan pengisian Jabatan Pimpinan Tinggi pada instansi Pemerintah. Output dari bentuk pengawasan KASN itu adalah surat rekomendasi baik saat rencana seleksi sampai selesai proses seleksi. Keseluruhan dari rekomendasi KASN berkaitan pengawasan pengisian jabatan impinan tinggi ini bersifat mengikat dan wajib ditindaklanjuti oleh Pejabat Pembina Kepegawaian dan Pejabat yang Berwenang. Atas hasil pengawasan yang tidak ditindaklanjuti, KASN merekomendasikan kepada Presiden untuk menjatuhkan sanki terhadap Pejabat Pembina Kepegawaian dan Pejabat Yang Berwenang atas pelanggaran prinsip Sistem Merit sesuai ketentuan peraturan perundang-undangan. Sanksi yang diberikan dapat berupa peringatan, teguran, perbaikan, pencabutan, pembatalan, penerbitan keputusan, dan/atau pengembalian pembayaran.

\section{a. Pengawasan Preventif}

Secara preventif KASN melakukan pembinaan dan sosialisasi terkait dengan kebijakan dan pelaksanaan Undang-Undang ASN yaitu Manajemen ASN berbasis sistem merit. Pembinaan ini bertujuan untuk memperkenalkan dan memberikan pemahaman kepada seluruh Instansi Pemerintah baik Pusat dan Daerah dalam melaksanaan seleksi terbuka. Sehingga Instansi dapat mempelajari lebih lanjut serta meminimalisir kesalahan atau pelanggaran yang akan mungkin terjadi. Selain itu juga, memberikan pemahaman mengenai tugas dan fungsi KASN. Namun disadari pelaksanaan pembinaan dan sosialisasi yang 
dilakukan sebagai bentuk pengawasan preventif KASN memiliki kendala yaitu terkait keterbatasan anggaran dan SDM. Terdapat sekitar 570 Instansi Pemerintah baik Pusat dan Daerah se-Indonesia, dibagi dua wilayah dengan masing-masing wilayah pengawasan sekitar 230an setiap Komisioner. Jumlah ini memang tidak sepadan dengan jumlah SDM dan Anggaran yang dimiliki oleh KASN. Oleh karena itu KASN tidak dapat melakukan pembinaan atau sosialisasi kepada seluruh wilayah, perlu adanya target target khusus terhadap Instansi Pemerintah yang kemungkinan besar terjadinya pelanggaran.

Dalam upaya untuk mempercepat proses pengawasan KASN dalam memeriksa dan memverifikasi dokumen-dokumen pengajuan seleksi terbuka, saat ini KASN sudah memiliki sistem yang bernama SIJAPTI yaitu Sistem Informasi Jabatan Pimpinan Tinggi. Sejak diluncurkan pada tahun 2016, aplikasi SIJAPTI ini sudah mendapat respon yang sangat baik dari Instansi Pemerintah Daerah karena dapat mempermudah dan mempercepat proses administrasi pengajuan seleksi dari setiap Instansi Pemerintah. Terutama saat terjadi pandemi covid saat ini, SIJAPTI dirasa sangat membantu Instansi Pemerintah dalam pengajuan pelaksaan seleksi terbuka ke KASN. Namun, saat ini KASN terus berupaya untuk mengembangan aplikasi SIJAPTI dengan menambahkan menu untuk proses promosi dan mutasi, karena saat ini dalam Aplikasi SIJPATI baru hanya diperuntukan untuk seleksi terbuka pengisian Jabatan pimpinan tinggi.

Setelah memeriksa dokumen pengajuan dan mengeluarkan rekomendasi persetujuan, KASN tetap terus mengawasi pelaksanaan seleksi terbuka dengan terjun langsung dalam proses pelaksanaan seleksi di Instansi Pemerintah. Proses ini bertujuan untuk melihat secara langsung proses yang berjalan untuk memastikan bahwa pelaksanaan seleksi terbuka ini sudah dilakukan sesuai tahapan-tahapan serta persyaratan yang di atur dalam peraturan yang berlaku, sehingga meminimalisir pelanggaran ataupun kecurangan yang kemungkinan akan terjadi.

\section{b. Pengawasan Represif}

Pengawasan represif dilakukan dengan pemeriksaan dokumen dokumen administrasi setelah pelaksanaan seleksi terbuka oleh Instansi Pemerintah. Sebelum KASN mengeluarkan rekomendasi untuk menyetujui hasil dari pelaksanaan seleksi terbuka tersebut, KASN harus memeriksa dokumen dan hasil setiap tahapan seleksi serta persyaratan yang diajukan apakah sudah sesuai dengan ketetapan atau belum. Apabila belum sesuai KASN akan mengeluarkan rekomendasi kepada PPK, untuk mendapatkan klarifikasi atas kecurangan yang dilakukan.

Pengawasan represif yang dilakukan KASN didasari atas kasus kasus pelanggaran yang terjadi saat pelaksaan pengisian jabatan pimpinan tinggi secara terbuka. Di KASN sendiri mempunyai tim mediasi dan perlindungan yang memiliki tugas untuk menginvestigasi laporan laporan terkait pelanggaran kasus seleksi terbuka. Untuk mempermudah proses pelaporan dan penanganan 
kasus pelanggaran, saat ini KASN sedang proses pembangunan aplikasi sistem informasi mediasi dan perlindungan (SIMELIN). Rencana pembangunan aplikasi SIMELIN ini dilatarbelakangi dengan banyaknya laporan dan pengaduan mengenai pelanggaran sistem merit yang berpotensi menjadi sengketa. Jika proses pengaduan atau laporan dilakukan secara langsung (datang ke kantor KASN) sedangkan para pelapor terdapat di seluruh Indonesia dan tentunya memerlukan sumber daya waktu, biaya dan tenaga sehingga dinilai kurang efektif dan efisien. Penggunaan teknologi dan informasi saat ini diperlukan untuk dapat memudahkan penyelesaian kasus sengketa ASN melalui proses mediasi dan perlindungan yang dilakukan secara online.

Dalam melakukan pengawasan, KASN membuka peluang kepada seluruh elemen masyarakat, baik masyarakat umum, Lembaga Swadaya Masyarakat, Non Government Organization, ataupun Aparatur Sipil Negara untuk dapat membantu mengawasi pelaksanaan manajemen ASN dan melaporkan kepada KASN apabila terjadi pelanggaraan. KASN sudah mempunyai sistem Lapor KASN yang berfungsi untuk mengawasi pelaksanaan Norma Dasar, Kode Etik, Kode Perilaku dan Netralitas ASN, serta menjamin pelaksanaan Sistem Merit pada Instansi Pemerintah berbasis elektronik. Dalam sistem lapor KASN tersebut, siapa pun dapat melaporkan keluhan atau temuan dengan jelas dan lengkap terkait dugaan pelanggaran yang kemudian laporan tersebut akan diverifikasi oleh Admin Lapor KASN untuk dapat ditindaklanjuti oleh Tim Pemeriksa. Setelah laporan pengaduan tersebut ditindaklanjuti oleh KASN, maka KASN akan menerbitkan rekomendasi atas tindaklanjut atau penyelesaian dugaan pelanggaran yang telah dilaporkan. Sistem Lapor KASN ini menjadi salah satu wadah bagi siapa pun untuk membantu KASN dalam mengawasi pelaksanaan manajemen ASN.

Dalam hal pengawasan pelaksanaan seleksi terbuka pengisian jabatan pimpinan tinggi di Instansi Pemerintah terutama mengatasi kasus pelanggaran seleksi terbuka pengisian JPT, KASN bekerjasama dengan instansi lain untuk menindaklanjuti kasus pelanggaran yang terjadi dan juga memberikan sanksi kepada instansi yang melanggar peraturan. Kondisi ini didasari karena kewenangan KASN hanya sebatas memberikan rekomendasi kepada PPK atas pelanggaran yang terjadi, namun KASN tidak dapat memberikan sanksi atau tidak dapat menindaklanjuti lebih lanjut. Oleh karena itu, dengan adanya pelaksanaan kerjasama yang dilakukan, diharapkan mampu mendukung percepatan Reformasi Birokasi guna penyelenggaraan pemerintah yang bersih, mensinergikan kewenangan sesuai tugas pokok dan fungsi KASN dengan stakeholders lainnya sebagai pembina, pengelenggara, pengawas, serta pelaksana manajemen ASN. Berikut bebeberapa Instansi Pemerintah yang bekerjsama dengan KASN dalam pengawasan pengisian Jabatan Pimpinan Tinggi di Instansi Pemerintah yaitu sebagai berikut: 
1) Kementerian Pendayagunaan Aparatur Negara dan Reformasi Birokrasi : KemenpanRB sebagai Instansi Pemerintah yang memiliki tugas dan fungsi untuk merumuskan kebijakan tentang ASN. Sedangkan, KASN sebagai lembaga pengawas pelaksanaan kebijakan manajemen ASN yang terjun langsung di lapangan, melihat segala bentuk resistensi, pro dan kontrak atas pelaksanaan peraturan yang ada. KASN akan melaporkan pelaksanaanan manajemen ASN tersebut kepada Kemenpan sebagai bahan evaluasi untuk Kemenpan dalam menyusun kebijakan manajemen ASN kedepannya.

2) Badan Kepegawaian Negara : Sejak tahun 2016 Ketua KASN dan Kepala BKN telah menandatangani nota kesepahaman (MoU) tentang Impelementasi Manajemen ASN berbasis merit sistem. Secara teknis, bentuk kerjasama KASN dengan BKN dalam menindaklanjuti pelanggaran yang terjadi saat pengisian jabatan pimpinan tinggi secara terbuka. KASN akan melaporkan kepada BKN, pegawai atau pejabat yang diangkat tanpa rekomendasi KASN. Sehingga BKN sebagai instansi yang memiliki wewenang dalam mengelola sistem administrasi kepegawaian seluruh Indonesia, dapat tidak memproses administrasi kepegawaian terhadap pejabat yang bersangkutan. Selain itu, BKN memiliki kantor wilayah (regional) di seluruh Indonesia yang dapat membantu KASN untuk mengawasi pelaksanaan manajemen ASN di berbagai daerah. Dalam proses pelaksanaan pembinaan manajaemen ASN berbasis sistem merit, KASN menggandeng kantor Regional BKN sesuai wilayahnya untuk membantu membina dan mengawasi penerapan sistem merit.

3) Kementerian Dalam Negeri : Kementerian Dalam Negeri membantu KASN dalam rangka mengawasi rekomendasi yang dikeluarkan KASN terkait pelaksanaan seleksi terbuka Pengisian Jabatan Pimpinan Tinggi di Instansi Pemerintah Daerah yang tidak sesuai dengan peraturan perundangundangan. Berikut beberapa peran yang dapat dilakukan oleh Kementerian Dalam Negeri dalam mengawal rekomendasi KASN yang diberikan kepada Kepala Daerah selaku PPK dalam manajemen ASN:

a) Mendorong pelaksanaan rekomendasi;

b) Pembinaan dan Pengawasan pelaksanaan rekomendasi;

c) Monitoring dan Evaluasi;

d) Supervisi atau meninjau pelaksanaan rekomendasi;

e) Penegakan sanksi kepada PPK yang tidak melaksanakan rekomendasi.

Oleh karena itu, KASN mempunyai perpanjangan tangan untuk menegur kepala daerah yang tidak melaksanakan rekomendasi KASN serta melanggar peraturan seleksi terbuka pengisian jabatan melalui Kementerian Dalam Negeri. 
4) Komisi Pemberantasan Korupsi : Pada tahun 2021, Ketua KPK dan Ketua KASN menandatangai Nota Kesepahaman tentang kerjasama dalam upaya pemberantasan tindak pidana korupsi dan pengawasan implementasi kebijakan manajemen ASN. Dalam hal pelaksanaan seleksi terbuka pengisian jabatan pimpinan tinggi, KASN sebagai lembaga pengawas yang turun langsung dilapangan, namun memiliki keterbatasan kewenangan untuk melakukan penindakan, sehingga KASN bekerjasama dengan KPK melaporkan apabila terdapat dugaan adanya kasus jual beli jabatan di Instansi Pemerintah Daerah. KPK sebagai instansi yang memiliki wewenang untuk melakukan penindakan serta eksekusi dapat langsung mengivenstigasi atas laporan yang diberikan oleh KASN tersebut.

5) Badan Pemeriksa Keuangan: KASN berencana untuk melakukan kerjasama dengan BPK dalam rangka memindaklanjuti pelanggaran pengisian jabatan pimpinan tinggi di Instansi Pemerintah. Apabila pengisian jabatan pimpinan tinggi tidak dilaksanakan dengan rekomendasi KASN dan tidak sesuai dengan peraturan yang berlaku, maka pejabat yang terpilih dianggap tidak sah menduduki jabatan tersebut. Oleh karena itu, segala bentuk kebijakan atau penggunaan anggaran juga dianggap tidak sah. Sehingga BPK dapat melakukan Tuntunan Ganti Rugi (TGR) kepada yang bersangkutan. Berdasarkan Peraturan Pemerintah Nomor 38 Tahun 2016 tentang Tata Cara Tuntutan Ganti Kerugian Negara/Daerah terhadap Pegawai Negeri Bukan Bendahara atau pejabat lain, menjelaskan bahwa Tuntutan Ganti Rugi selanjutnya disingkat (TGR) adalah suatu proses penuntutan yang dilakukan terhadap pegawai negeri sipil bukan bendahara dengan tujuan untuk menuntut penggantian atas suatu kerugian yang diderita oleh Negara sebagai akibat langsung ataupun tidak langsung dari suatu perbuatan melanggar hukum dan/atau kelalaian yang dilakukan oleh Pegawai Negeri Sipil bukan bendahara tersebut dalam melaksanakan tugas, fungsi dan jabatannya.

\section{Manajemen Talenta}

Manajemen talenta merupakan salah satu komponen utama dari human capital management yang berfokus pada Sumber Daya Manusia, kegiatan-kegiatan pengelolaan SDM yang diperlukan untuk memastikan keberhasilan strategi organisasi. Management talenta dapat diartikan pula sebagai manajemen strategi untuk mengelola aliran talenta dalam organisasi dengan tujuan memastikan tersedianya pasokan talenta sesuai dengan tujuan strategis dan visi misi organisasi. Dengan adanya penerapan manajemen talenta dapat memastikan kemampuan organisasi untuk mengisi posisi kunci pemimpin masa depan dan posisi yang mendukung kompetensi inti organisasi dan memastikan bahwa posisi-posisi kunci tersebut bisa diisi dari internal organisasi melalui proses pengembangan talenta.

Penerapan manajemen talenta di Indonesia sendiri mulai tercetus didalam Undang-Undang ASN, sebagai tujuan utama dalam menerapakan manajemen ASN 
berbasis sistem merit. Sedangkan pelaksanaan seleksi terbuka pengisian jabatan pimpinan tinggi di Indonesia merupakan sebuah proses untuk menuju penerapan manajemen talenta. Karena disadari bahwa penerapan manajemen talenta bukanlah suatu hal yang mudah, dibutuhkan waktu yang lama, perubahan secara sistem dan peraturan yang ada, serta biaya yang cukup tinggi. Namun saat ini, pemaknaan manajemen talenta diartikan sebagai manajemen talenta instritusional bukan manajemen talenta nasional. Hal ini diakibatkan karena pada pasal 111 UndangUndang No. 5 Tahun 2014 tentang ASN menyebutkan bahwa Ketentuan Pengisian Jabatan Tinggi dapat dikecualikan pada Instansi Pemerintah yang telah menerapakan Sistem Merit dalam Pembinaan Pegawai ASN dengan persetujuan KASN. Pasal ini diartikan oleh banyak pihak bahwa apabila instansi sudah menerapkan sistem merit maka tidak perlu lagi untuk melakukan pengisian jabatan pimpinan tinggi secara terbuka. Oleh karena itu saat ini banyak Instansi Pemerintah yang berbondong bondong untuk menerapkan sistem merit, karena dengan alasan ingin melakukan pengisian JPT secara terbatas. Kondisi ini dikhawatirkan manajemen ASN akan kembali menjadi close career system karena seleksi dilakukan secara terbatas di dalam Instansi masing-masing.

Hal ini harus diluruskan kepada seluruh Instansi bahwa pengecualian seleksi terbuka tersebut bukan lah memberikan kebebasan kepada Instansi Pemerintah untuk melakukan pengisian jabatan tanpa seleski, namun harus mempunyai manajemen talenta terlebih dahulu dan tetap berkoordinasi dengan KASN. KASN sebagai lembaga pengawas akan mempunyai tanggung jawab lebih besar apabila Instansi Pemerintah telah mempunyai manajemen talenta, karena harus benar benar memastikan calon suksesor yang ada di dalam manajemen talenta tersebut apakah sudah sesuai atau belum untuk mengisi jabatan yang akan lowong. Besar harapan manajemen talenta yang akan dibangun secara nasional ini dapat memberikan kemudahan manajemen ASN untuk mendapatkan calon suksesor yang memiliki kompetensi, kinerja, dan profesional serta dilakukan dengan transparan, adil dan obyektif.

\section{Kesimpulan}

Pelaksanaan seleksi terbuka pengisian jabatan pimpinan tinggi di Instansi Pemerintah baik Pusat dan Daerah merupakan metode yang terbaik untuk mendapatkan pejabat pejabat yang berkompeten dan berkinerja tinggi untuk saat ini. Meskipun dibalik pelaksanannya tersebut masih terdapat beberapa kelemahan, namun seleksi terbuka pengisian jabatan pimpinan tinggi ini sudah dapat merubah proses pengisian jabatan dari close career system menjadi open career system. Sehingga adanya resistensi ataupun kelemahan yang ada dapat dimaklumi sebagai sebuah sistem yang baru, dimana tidak semua orang bisa dapat langsung menerimanya. Pengawasan yang dilakukan KASN pun sudah cukup baik, secara preventif ataupun represif. Sebagai lembaga baru yang terbentuk pada tahun 2014 dan dengan segala keterbatasan yang ada, KASN sudah dapat membuktikan kinerjanya. KASN sudah dapat membangun sebuah sistem, 
membangun kepercayaan masyarakat akan pengawasan manajemen ASN, secara perlahan membangun reformasi birokrasi dari sektor manajemen ASN. Sebagai lembaga pengawas, manajemen ASN di Indonesia dapat di kontrol agar sesuai dengan peraturan yang telah ditetapkan karena ada KASN sebagai wasit yang dapat menegur secara langsung apabila terjadi pelanggaran.

Kedepannya pelaksanaan pengisian jabatan diharapkan dapat melalui manajemen talenta nasional. Pembangunan manajemen talenta nasional ini menjadi impian besar bagi seluruh ASN di Indonesia karena pelaksanaan manajemen ASN dilakukan dengan sangat terbuka, biaya yang lebih murah dan proses yang lebih cepat ketika sudah terbangun. Maka ketika terdapat jabatan yang lowong di suatu Instansi Pemerintah, dapat langsung diisi dari manajemen talenta nasional tersebut dengan pejabat yang bertalenta dan sesuai dengan kompetensi yang dibutuhkan. Namun memang sangat disadari pembangunan manajemen talenta ini cukup memakan waktu dan biaya. Oleh karena itu saat ini beberapa stakeholders sedang terus berupaya untuk menuju pembangunan manajemen talenta nasional, disamping itu sampai pembangunan tersebut selesai maka dilaksanakanlah metode seleksi terbuka pengisian jabatan pimpinan tinggi sebagai transisi sementara dan quick win dalam menerapan sistem merit dalam manajemen ASN di Indonesia. 
Della Damayanti, Mahendro Sumardjo, Alfatih S. Manggabarani

\section{BIBLIOGRAFI}

Achmad, Winasty. (2017). Kekuatan Politik Abdul Aziz Qahar Mudzakkar pada Pemilu Legislatif Tahun 2014 (Studi di Kel. Tanete, Kec. Anggeraja, Kab. Enrekang). Universitas Islam Negeri Alauddin Makassar. Google Scholar

Ali, Desy Mutia, Prasojo, Eko, \& Lina, M. J. (2017). The Transformation of Merit System in Indonesian Civil Servant Promotion System. International Journal of Management and Administrative Sciences, 5(4), 20-28. Google Scholar

Ashraf, Junaid. (2017). Examining the public sector recruitment and selection, in relation to job analysis in Pakistan. Cogent Social Sciences, 3(1), 1309134. Google Scholar

Barusman, M. Yusuf S. (2018). Decision making model of electric power fulfillment in lampung province using soft system methodology. Google Scholar

Dwiputrianti, Septiana. (2018). Challenges With Implementation Of The Merit System In The Open Recruitment Of Government High Positions: The Case In Indonesia. 2018 Annual Conference of Asian Association for Public Administration:" Reinventing Public Administration in a Globalized World: A Non-Western Perspective"(AAPA 2018), 70-80. Atlantis Press. Google Scholar

Ifaistion, Papapolychroniadis, Ioannis, Rossidis, \& George, Aspridis. (2017). Comparative analysis of recruitment systems in the public sector in Greece and Europe: Trends and outlook for staff selection systems in the Greek public sector. Academic Journal of Interdisciplinary Studies, 6(1), 21. Google Scholar

Irfan, M. (2017). Operasionalisasi Talent Management di Lingkup Pegawai Negeri Sipil. Jakarta: Badan Kepegawaian Negara. Google Scholar

Isaac Christopher Otoo, Juliet Assuming, dan Paul Mensah Agyei. (2018). "Effctiveness of Recruitment and Selection Practices in Public Sector Higher Education Institutions : Evidence from Ghana."

Noors, Adima Insan Akbar. (2019). Analisis Pelaksanaan Seleksi Terbuka bagi Pengisian Jabatan Pimpinan Tinggi di Indonesia. Konferensi Nasional Ilmu Administrasi, 3(1). Google Scholar

Sajeena, U. (2017). Recruitment And Selection Strategies Of Public Sector Undertakings. International Journal Of Research-Granthaalayah, 5(2), 333-337. Google Scholar

Sugiyono. (2017). Metode Penelitian Kuantitatif, Kualitatif, dan R\&D. Alfabeta: Bandung Google Scholar

Suwitri, Sri, Supriyono, Bambang, Sulastri, Sri, \& Kuswandaru, Otok. (2019). Transactional Politics in Filling High Leadership Positions in Indonesian 
Analisis Pengawasan Seleksi Terbuka Pengisian Jabatan Pimpinan Tinggi Di Instansi Pemerintah oleh Komisi Aparatur Sipil Negara (KASN)

Bureaucratic Organizations. Google Scholar

Yusuf, Marissa Fitrianda. (2018). Pengaruh Sistem Manajemen Kinerja Individu (SMKI), Kompetensi, Dan Promosi Jabatanterhadap Kinerja Karyawan PadA PT. PGN (PERSERO) Tbk Sbu Ii Surabaya. Universitas Narotama. Google Scholar

\section{Copyright holder:}

Della Damayanti, Mahendro Sumardjo, Alfatih S. Manggabarani (2022)

\section{First publication right:}

Syntax Literate: Jurnal Ilmiah Indonesia

This article is licensed under:

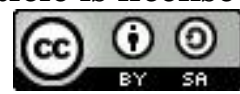

